\title{
Changes in TNF- $\alpha$, IL-6, IL-10 and VEGF in rats with ARDS and the effects of dexamethasone
}

\author{
MENGTING QIN $^{1}$ and ZHONGPENG QIU ${ }^{2}$ \\ Departments of ${ }^{1}$ Critical Care Medicine and ${ }^{2}$ Orthopedics, The First Affiliated Hospital \\ of Medical College, Shihezi University, Shihezi, Xinjiang 832002, P.R. China
}

Received April 19, 2018; Accepted October 19, 2018

DOI: 10.3892/etm.2018.6926

\begin{abstract}
Changes in tumor necrosis factor- $\alpha$ (TNF- $\alpha$ ), interleukin-6 (IL-6), IL-10 and vascular endothelial growth factor (VEGF) in serum and bronchoalveolar lavage fluid (BALF) in rats with acute respiratory distress syndrome (ARDS) and the intervention effect of dexamethasone were observed to explore the theoretical basis of dexamethasone in the treatment of ARDS. Seventy-two rats were randomly divided into normal control group (group $\mathrm{N}, \mathrm{n}=24$ ), ARDS model group (group L, $\mathrm{n}=24$ ) and dexamethasone group (group $\mathrm{D}, \mathrm{n}=24$ ). The ARDS rat model was established by jointly injecting oleic acid and lipopolysaccharide via the caudal vein, while rats in group D received intervention with dexamethasone. The wet/dry weight ratios of lung tissues were measured, and the levels of TNF- $\alpha$, IL-6, IL-10 and VEGF in serum and BALF were measured via enzyme-linked immunosorbent assay. The wet/dry weight ratio of lung tissues of rats in group $\mathrm{D}$ was significantly decreased compared with that in group $\mathrm{L}(\mathrm{P}<0.05$ or $\mathrm{P}<0.01)$. The levels of TNF- $\alpha$, IL- 6 and VEGF in serum and BALF of rats in group $\mathrm{L}$ and $\mathrm{D}$ were obviously increased compared with those in group $\mathrm{N}$ at each time point $(\mathrm{P}<0.01)$. The levels of TNF- $\alpha$, IL- 6 and VEGF in serum and BALF of rats in group D were significantly decreased compared with those in group L $(\mathrm{P}<0.01)$. In conclusion, there is a serious imbalance between anti-inflammatory response and inflammatory response in rats with ARDS induced by oleic acid combined with lipopolysaccharide of Escherichia coli, whereas dexamethasone can alleviate lung injury through inhibiting expression levels of inflammatory factors and promoting expression levels of anti-inflammatory factors.
\end{abstract}

Correspondence to: Dr Mengting Qin, Department of Critical Care Medicine, The First Affiliated Hospital of Medical College, Shihezi University, 107 North Road, Shihezi, Xinjiang 832002, P.R. China E-mail: qinmengtingxj@163.com

Key words: acute respiratory distress syndrome, dexamethasone, cytokines

\section{Introduction}

Acute respiratory distress syndrome (ARDS) refers to diffuse alveolar inflammation and damage to the capillary wall secondary to severe trauma, shock, infection and other factors, resulting in pulmonary edema and ultimately leading to severe hyoxemia and carbon dioxide emission disorder (1). The main clinical manifestations of ARDS are extreme difficulty in breathing, cyanosis, increased heart rate, and diffuse infiltrated shadow shown in pulmonary X-ray (2). In recent years, the incidence rate of ARDS has increased significantly with an annual incidence of approximately 59/100,000, but the prognosis is still poor, and the mortality rate is still as high as $30 \%(3,4)$. Clinical diagnosis and treatment of ARDS are very challenging (5). With the constant research on ARDS, the current clinical treatment methods of ARDS include protective pulmonary ventilation therapy, prone position ventilation, high positive end expiratory pressure (PEEP) and high frequency ventilation, but they cannot effectively reduce the fatality rate of ARDS, and some patients eventually suffer from pulmonary fibrosis, leading to permanent lung dysfunction (6). The pathogenesis of ARDS is complex, one of which is excessive and extensive inflammatory response of lung tissues after the attack of various pathogenic factors (7). Glucocorticoids have a potent anti-inflammatory effect, which can interfere in inflammatory signaling pathways mediated by various cytokines (8), thereby hindering the occurrence and development of pulmonary fibrosis. In this study, therefore, the ARDS rat model was established via oleic acid combined with lipopolysaccharide (LPS) of Escherichia coli, changes in tumor necrosis factor- $\alpha$ (TNF- $\alpha$ ), interleukin-6 (IL-6), IL-10 and vascular endothelial growth factor (VEGF) in ARDS rats were observed at different time points, and the effects of dexamethasone on them were also observed, so as to preliminarily investigate the pathogenesis of ARDS, and provide a theoretical basis for the clinical application of dexamethasone in ARDS.

\section{Materials and methods}

Materials. Dexamethasone injection (Shandong LukangCisen Pharmaceutical Co., Ltd., Jining, China, NMPN H37021969), oleic acid and LPS (Sigma-Aldrich; Merck KGaA, Darmstadt, Germany), urethane (Shandong Qilu Xinghua 
Pharmaceutical Co. Ltd., Jining, China), TNF- $\alpha$, IL-6, IL-10 and VEGF enzyme-linked immunosorbent assay (ELISA) kits (Sigma-Aldrich; Merck KGaA), clean bench (Shanghai Boxun Industrial Co., Ltd., Shanghai, China), electronic balance (Sartorius AG, Göttingen Germany), and continuous wavelength multifunctional microplate reader (Tecan Austria $\mathrm{GmbH}$, Grödje, Austria). This study was approved by the Animal Ethics Committee of Shihezi University Animal Center (Shihezi, China).

Experimental animal grouping and preparation. A total of 72 specific pathogen-free (SPF) Sprague-Dawley (SD) rats (equal number of males and females) aged 12-13 weeks weighing 200-220 g were purchased from Shanghai SLAC Laboratory Animal Center, Shanghai, China [license no: SCXK (Shanghai) 2012-0002], and divided into 4 groups using a random number table: Normal control group ( $\mathrm{N}, \mathrm{n}=24)$, ARDS model group ( $\mathrm{L}, \mathrm{n}=24)$ and dexamethasone group $(\mathrm{D}, \mathrm{n}=24)$. Rats in group $\mathrm{N}$ were injected with $5 \mathrm{ml} / \mathrm{kg}$ normal saline via the caudal vein, rats in $\mathrm{L}$ were injected with $0.05 \mathrm{ml} / \mathrm{kg}$ oleic acid via the caudal vein and $2.5 \mathrm{mg} / \mathrm{kg}$ LPS after $30 \mathrm{~min}$, and rats in D were injected with $0.05 \mathrm{ml} / \mathrm{kg}$ oleic acid via the caudal vein and $2.5 \mathrm{mg} / \mathrm{kg}$ LPS and $6 \mathrm{mg} / \mathrm{kg}$ dexamethasone after $30 \mathrm{~min}$. Rats were kept in cage with controlled temperature and light cycles $\left(24^{\circ} \mathrm{C}\right.$ and $12 / 12$ light cycles) and free access to food and water, humidity was $60 \pm 10 \%$.

Observation time points. After rats in the three groups were injected twice, they were observed at three different time points $(4,8$ and $12 \mathrm{~h}), 8$ rats at each time point.

Specimen collection. At corresponding time points, rats were anesthetized via intraperitoneal injection of $1 \mathrm{~g} / \mathrm{kg} 20 \%$ urethane. The blood was collected from the abdominal aorta and centrifuged at $1,610 \mathrm{x} \mathrm{g}$ at $4^{\circ} \mathrm{C}$ for $15 \mathrm{~min}$ to separate the serum, and the serum was stored at $-80^{\circ} \mathrm{C}$. The chest was quickly opened, the right hilus of the lung was ligated, right lung tissues were removed, and the wet weight of right lung was measured. Then the right lung was baked in a constanttemperature drying box at $80^{\circ} \mathrm{C}$ until constant weight, and the dry weight of right lung was measured. The wet/dry weight ratio of right lung tissues was calculated. The front end of catheter with $1.8 \mathrm{~mm}$ in external diameter was inserted into the bifurcation of the lower left principal bronchus, and $2.5 \mathrm{ml}$ normal saline at $37^{\circ} \mathrm{C}$ was slowly injected via catheter for bronchoalveolar lavage. Bronchoalveolar lavage fluid (BALF) was recycled, and the lavage was repeated 5 times. The recycled BALF was collected into a centrifuge tube and centrifuged at $402 \mathrm{x} \mathrm{g}$ at $4^{\circ} \mathrm{C}$ for $10 \mathrm{~min}$. The supernatant was separated and stored at $-80^{\circ} \mathrm{C}$ for standby application.

Detection of inflammatory factors in serum and BALF. An appropriate amount of serum and BALF was taken, followed by loading and treatment in strict accordance with instructions of the ELISA kit. The optical density (OD) value was detected using the continuous wavelength multifunctional microplate reader (Tecan Austria GmbH, Grödje,Austria), and the standard curves were drawn. TNF- $\alpha$, IL-6, IL-10 and VEGF protein levels in each sample were calculated.

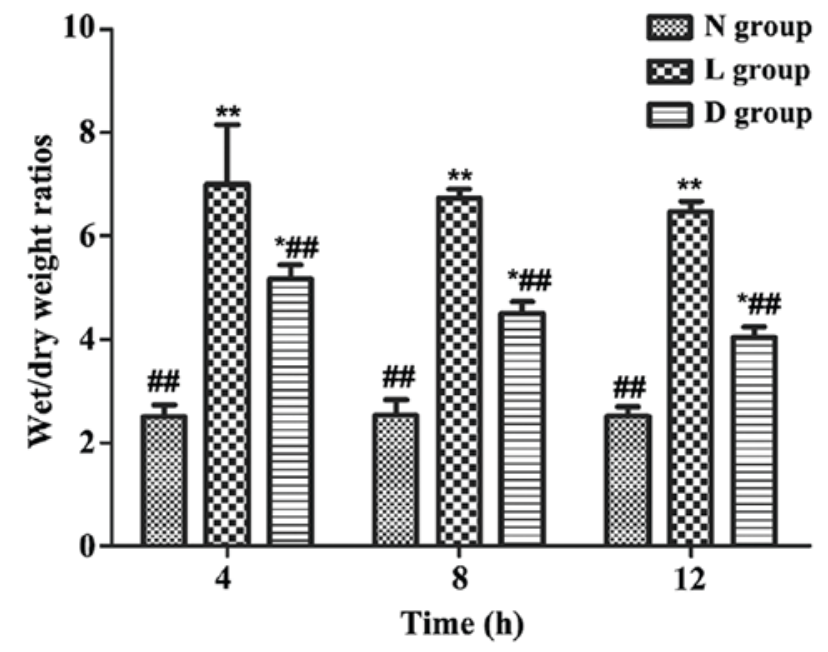

Figure 1. Comparison of wet/dry weight ratio of lung tissues of rats in each group. The wet/dry weight ratio of lung tissues of rats in group $\mathrm{L}$ is significantly increased compared with that in group $\mathrm{N}(\mathrm{P}<0.01)$. The wet/dry weight ratio of lung tissues of rats in group $\mathrm{D}$ is significantly increased compared with that in group $\mathrm{N}(\mathrm{P}<0.05$ or $\mathrm{P}<0.01)$, but significantly decreased compared with that in group $\mathrm{L}(\mathrm{P}<0.05$ or $\mathrm{P}<0.01)$. ${ }^{*} \mathrm{P}<0.05 ;{ }^{* *} \mathrm{P}<0.01$ vs. group $\mathrm{N}$; ${ }^{\#} \mathrm{P}<0.01$ vs. group $\mathrm{L}$.

Table I. Changes in serum TNF- $\alpha$ content in rats $(\mathrm{ng} / \mathrm{l}, \mathrm{n}=8)$.

\begin{tabular}{lccc}
\hline Groups & $4 \mathrm{~h}$ & $8 \mathrm{~h}$ & $12 \mathrm{~h}$ \\
\hline $\mathrm{N}$ & $58.39 \pm 3.02$ & $57.64 \pm 3.33$ & $58.91 \pm 3.87$ \\
$\mathrm{~L}$ & $375.52 \pm 8.63^{\mathrm{a}}$ & $358.40 \pm 9.19^{\mathrm{a}}$ & $337.65 \pm 10.24^{\mathrm{a}}$ \\
$\mathrm{D}$ & $261.07 \pm 9.40^{\mathrm{a}, \mathrm{b}}$ & $228.75 \pm 8.66^{\mathrm{a}, \mathrm{b}}$ & $202.87 \pm 9.91^{\mathrm{a}, \mathrm{b}}$
\end{tabular}

${ }^{\mathrm{a}} \mathrm{P}<0.01$ vs. group $\mathrm{N}$; ${ }^{\mathrm{b}}<0.01$ vs. group $\mathrm{L}$.

Statistical analysis. Experimental results are presented as (mean \pm SD), and SPSS 20.0 software (IBM Corp., Armonk, NY, USA) was used for statistical analysis of data. Independentsamples t-test was used for the comparison between two groups, and one-way analysis of variance was used for the comparison among groups and the post hoc test was Dunnett's test. $\mathrm{P}<0.05$ was considered to indicate a statistically significant difference.

\section{Results}

Wet/dry weight ratio of lung tissues. The wet/dry weight ratio of lung tissues of rats in group L was significantly increased compared with that in group $\mathrm{N}(\mathrm{P}<0.01)$. The wet/dry weight ratio of lung tissues of rats in group $D$ was significantly decreased compared with that in $\mathrm{L}(\mathrm{P}<0.05$ or $\mathrm{P}<0.01)$, and the decrease was the most significant at $12 \mathrm{~h}$, but it was still significantly higher than that in $\mathrm{N}(\mathrm{P}<0.05$ or $\mathrm{P}<0.01$ ) (Fig. 1).

Changes in serum TNF- $\alpha, I L-6, I L-10$ and VEGF levels. The levels of serum TNF- $\alpha$, IL- 6 and VEGF in rats in group L and D were obviously increased compared with those in group $\mathrm{N}$ at each time point $(\mathrm{P}<0.01)$, but the levels of IL-10 were obviously decreased compared with that in 
Table II. Changes in serum IL-6 content in rats $(\mathrm{ng} / \mathrm{l}, \mathrm{n}=8)$.

\begin{tabular}{lccc}
\hline Groups & $4 \mathrm{~h}$ & $8 \mathrm{~h}$ & $12 \mathrm{~h}$ \\
\hline $\mathrm{N}$ & $4.46 \pm 0.08$ & $4.39 \pm 0.08$ & $4.44 \pm 0.10$ \\
$\mathrm{~L}$ & $28.55 \pm 1.17^{\mathrm{a}}$ & $22.08 \pm 1.04^{\mathrm{a}}$ & $19.69 \pm 1.42^{\mathrm{a}}$ \\
$\mathrm{D}$ & $16.21 \pm 0.75^{\mathrm{a}, \mathrm{b}}$ & $13.21 \pm 0.82^{\mathrm{a}, \mathrm{b}}$ & $10.22 \pm 0.83^{\mathrm{a}, \mathrm{b}}$
\end{tabular}

${ }^{\mathrm{a}} \mathrm{P}<0.01$ vs. group $\mathrm{N}$; ${ }^{\mathrm{b}} \mathrm{P}<0.01$ vs. group $\mathrm{L}$.

Table III. Changes in serum IL-10 content in rats $(\mathrm{ng} / \mathrm{ml}, \mathrm{n}=8)$.

\begin{tabular}{llll}
\hline Groups & \multicolumn{1}{c}{$4 \mathrm{~h}$} & \multicolumn{1}{c}{$8 \mathrm{~h}$} & $12 \mathrm{~h}$ \\
\hline $\mathrm{N}$ & $72.51 \pm 3.48$ & $74.09 \pm 3.62$ & $72.76 \pm 3.23$ \\
$\mathrm{~L}$ & $37.24 \pm 2.81^{\mathrm{a}}$ & $40.16 \pm 3.06^{\mathrm{a}}$ & $43.58 \pm 3.20^{\mathrm{a}}$ \\
$\mathrm{D}$ & $48.82 \pm 3.55^{\mathrm{a}, \mathrm{b}}$ & $53.00 \pm 3.54^{\mathrm{a}, \mathrm{b}}$ & $59.17 \pm 3.29^{\mathrm{a}, \mathrm{b}}$ \\
\hline
\end{tabular}

${ }^{\mathrm{a}} \mathrm{P}<0.01$ vs. group $\mathrm{N} ;{ }^{\mathrm{b}} \mathrm{P}<0.01$ vs. group $\mathrm{L}$.

Table IV. Changes in serum VEGF content in rats $(\mathrm{pg} / \mathrm{ml}, \mathrm{n}=8)$.

\begin{tabular}{lccc}
\hline Groups & $4 \mathrm{~h}$ & \multicolumn{1}{c}{$8 \mathrm{~h}$} & \multicolumn{1}{c}{$12 \mathrm{~h}$} \\
\hline $\mathrm{N}$ & $22.05 \pm 4.01$ & $23.19 \pm 3.77$ & $22.81 \pm 3.64$ \\
$\mathrm{~L}$ & $73.42 \pm 4.54^{\mathrm{a}}$ & $70.30 \pm 3.68^{\mathrm{a}}$ & $66.99 \pm 4.82^{\mathrm{a}}$ \\
$\mathrm{D}$ & $47.53 \pm 4.22^{\mathrm{a}, \mathrm{b}}$ & $38.51 \pm 3.80^{\mathrm{a}, \mathrm{b}}$ & $34.06 \pm 3.56^{\mathrm{a}, \mathrm{b}}$ \\
\hline
\end{tabular}

${ }^{\mathrm{a}} \mathrm{P}<0.01$ vs. group $\mathrm{N} ;{ }^{\mathrm{b}} \mathrm{P}<0.01$ vs. group $\mathrm{L}$.

group $\mathrm{N}(\mathrm{P}<0.01)$. The levels of serum TNF- $\alpha$, IL- 6 and VEGF in rats in group $\mathrm{D}$ were significantly decreased compared with those in $\mathrm{L}(\mathrm{P}<0.01)$, but the level of IL-10 was significantly increased compared with that in group $\mathrm{L}$ $(\mathrm{P}<0.01)$ (Tables I-IV).

Changes in TNF- $\alpha, I L-6, I L-10$ and VEGF levels in BALF. The levels of TNF- $\alpha$, IL- 6 and VEGF in BALF of rats in group $\mathrm{L}$ and $\mathrm{D}$ were obviously increased compared with those in group $\mathrm{N}$ at each time point $(\mathrm{P}<0.01)$, but the levels of IL-10 were obviously decreased compared with that in group $\mathrm{N}$ $(\mathrm{P}<0.01)$. The levels of TNF- $\alpha$, IL-6 and VEGF in BALF of rats in group $\mathrm{D}$ were significantly decreased compared with those in $\mathrm{L}(\mathrm{P}<0.01)$, but the level of IL-10 was significantly increased compared with that in group L $(\mathrm{P}<0.01)$ (Tables V-VIII).

\section{Discussion}

At present, ARDS animal models include hydrochloric acid aspiration-type, whole lung lavage-type, endotoxin-type and oleic acid-type models, among which endotoxin-type and oleic acid-type models are the most widely used (9). Studies have shown that oleic acid can directly contract pulmonary arterial vessels, damage the alveolar capillary endothelium, and cause increased permeability of pulmonary capillary, and
Table V. Changes in TNF- $\alpha$ content in BALF of rats $(n g / l, n=8)$.

\begin{tabular}{lccc}
\hline Groups & $4 \mathrm{~h}$ & $8 \mathrm{~h}$ & $12 \mathrm{~h}$ \\
\hline $\mathrm{N}$ & $92.37 \pm 4.02$ & $91.55 \pm 3.73$ & $91.81 \pm 2.96$ \\
$\mathrm{~L}$ & $566.07 \pm 10.24^{\mathrm{a}}$ & $528.79 \pm 12.11^{\mathrm{a}}$ & $495.38 \pm 11.45^{\mathrm{a}}$ \\
$\mathrm{D}$ & $420.05 \pm 12.55^{\mathrm{a}, \mathrm{b}}$ & $406.67 \pm 13.20^{\mathrm{a}, \mathrm{b}}$ & $387.73 \pm 12.97^{\mathrm{a}, \mathrm{b}}$
\end{tabular}

${ }^{\mathrm{a}} \mathrm{P}<0.01$ vs. group $\mathrm{N} ;{ }^{\text {b }} \mathrm{P}<0.01$ vs. group $\mathrm{L}$.

Table VI. Changes in IL-6 content in BALF of rats $(n g / l, n=8)$.

\begin{tabular}{lccc}
\hline Groups & $4 \mathrm{~h}$ & $8 \mathrm{~h}$ & $12 \mathrm{~h}$ \\
\hline $\mathrm{N}$ & $6.66 \pm 0.09$ & $6.61 \pm 0.06$ & $6.72 \pm 0.11$ \\
$\mathrm{~L}$ & $38.81 \pm 1.25^{\mathrm{a}}$ & $31.74 \pm 1.40^{\mathrm{a}}$ & $28.58 \pm 1.19^{\mathrm{a}}$ \\
$\mathrm{D}$ & $25.17 \pm 1.33^{\mathrm{a}, \mathrm{b}}$ & $22.60 \pm 0.95^{\mathrm{a}, \mathrm{b}}$ & $18.15 \pm 1.17^{\mathrm{a}, \mathrm{b}}$
\end{tabular}

${ }^{\mathrm{a}} \mathrm{P}<0.01$ vs. group $\mathrm{N}$; ${ }^{\mathrm{b}} \mathrm{P}<0.01$ vs. group $\mathrm{L}$.

Table VII. Changes in IL-10 content in BALF of rats $(\mathrm{ng} / \mathrm{ml}$, $\mathrm{n}=8$ ).

\begin{tabular}{lccc}
\hline Groups & \multicolumn{1}{c}{$4 \mathrm{~h}$} & \multicolumn{1}{c}{$8 \mathrm{~h}$} & $12 \mathrm{~h}$ \\
\hline $\mathrm{N}$ & $78.40 \pm 3.39$ & $78.61 \pm 3.33$ & $77.89 \pm 3.52$ \\
$\mathrm{~L}$ & $30.06 \pm 2.21^{\mathrm{a}}$ & $34.92 \pm 3.12^{\mathrm{a}}$ & $36.95 \pm 2.47^{\mathrm{a}}$ \\
$\mathrm{D}$ & $54.18 \pm 3.70^{\mathrm{a}, \mathrm{b}}$ & $58.43 \pm 3.45^{\mathrm{a}, \mathrm{b}}$ & $64.71 \pm 3.66^{\mathrm{a}, \mathrm{b}}$
\end{tabular}

${ }^{\mathrm{a}} \mathrm{P}<0.01$ vs. group $\mathrm{N}$; ${ }^{\mathrm{b}} \mathrm{P}<0.01$ vs. group $\mathrm{L}$.

Table VIII. Changes in VEGF content in BALF of rats $(\mathrm{pg} / \mathrm{ml}$, $\mathrm{n}=8)$.

\begin{tabular}{lccc}
\hline Groups & $4 \mathrm{~h}$ & \multicolumn{1}{c}{$8 \mathrm{~h}$} & $12 \mathrm{~h}$ \\
\hline $\mathrm{N}$ & $20.36 \pm 2.87$ & $20.52 \pm 3.19$ & $19.85 \pm 3.74$ \\
$\mathrm{~L}$ & $81.17 \pm 4.26^{\mathrm{a}}$ & $76.45 \pm 5.08^{\mathrm{a}}$ & $72.63 \pm 4.00^{\mathrm{a}}$ \\
$\mathrm{D}$ & $56.54 \pm 3.81^{\mathrm{a}, \mathrm{b}}$ & $48.02 \pm 3.44^{\mathrm{a}, \mathrm{b}}$ & $29.76 \pm 4.62^{\mathrm{a}, \mathrm{b}}$ \\
\hline
\end{tabular}

${ }^{\mathrm{a}} \mathrm{P}<0.01$ vs. group $\mathrm{N}$; ${ }^{\mathrm{b}} \mathrm{P}<0.01$ vs. group $\mathrm{L}$.

a large amount of fluid and protein exudation, thus leading to the occurrence of ARDS (10). However, LPS is the major component of endotoxin, which has less effect on the direct damage to lung tissues (11). Besides, LPS mainly activates macrophages, releases a large number of pro-inflammatory factors, and activates polymorphonuclear leukocytes, thus making the body enter systemic inflammatory response state. Systemic inflammatory response can further damage the lung tissues, eventually resulting in ARDS (12). Therefore, oleic acid mainly destroys the pulmonary vascular endothelial cells, causing increased vascular permeability and a large amount of 
fluid exudation, and leading to pulmonary edema. LPS leads to inflammatory response of lung tissues mainly through the inflammatory cascade reaction. Studies suggest that in pathogenesis of ARDS, in addition to direct lung damage caused by trauma, infection and other primary causes, there are also 'second-strike' factors due to intestinal bacterial toxins into the blood and surgical trauma (13). Therefore, in this study, the 'second-strike' ARDS animal model was established using oleic acid combined with LPS to better simulate the pathogenetic process of human ARDS. It was observed and found in this study that after injection of oleic acid and LPS into rats in group L and group D, cyanosis in four limbs, respiratory distress, decreased activity, piloerection, pulmonary edema and rise in inflammatory indexes occurred, indicating successful modeling.

The pathogenesis of ARDS is very complicated and has not been fully elucidated so far. In recent years, the research of a large number of scholars worldwide on its pathogenesis mainly focuses on the regulatory mechanism of lung tissue inflammation and pulmonary edema (14). Early ARDS is characterized by increased permeability of alveolar epithelial cells and pulmonary capillary endothelial cells, and a large amount of fluid exudation between alveoli and lung interstitium, while the exudate mainly contains a variety of inflammatory cells dominated by neutrophils. Neutrophils can further adhere and gather on the surface of damaged vascular endothelial cells, and migrate to the interstitium and alveolar space, promoting the release of a large number of inflammatory mediators and ultimately exacerbating the inflammatory response in lung tissues (15).

In trauma, infection occurs in the body, macrophages are activated, producing and releasing a large amount of TNF- $\alpha$. TNF- $\alpha$ can damage the vascular endothelium, destroy its barrier function, and cause increased capillary permeability and a large amount of fluid exudation, forming pulmonary edema, and thus inducing ARDS (16). At the same time, in the entire course of ARDS, TNF- $\alpha$ can reduce the production of antioxidants, leading to reduced scavenging of oxygen free radicals, thereby aggravating tissue damage, and causing disease exacerbation and progression (17). At the same time, TNF- $\alpha$, as the most important pro-inflammatory factor in early inflammatory response, can promote the formation of a large number of IL family members, thereby exacerbating the body's inflammatory response (18). IL-6 is a key inflammatory factor that induces inflammatory cascade reaction in ARDS, which is mainly secreted by $\mathrm{T}$ cells, monocytes-macrophages and endothelial cells. Besides, it activates neutrophils to mediate the secretion of a large number of acute-phase proteins in the liver, ultimately promoting acute inflammatory response (19). VEGF is the strongest vascular permeability factor in the body, which can increase vascular permeability in multiple organ systems, causing local exudation and inflammatory response (20). VEGF can increase the permeability of pulmonary vascular endothelial cells in ARDS, aggravate pulmonary edema, enlarge and continue the body's inflammatory response, promoting the occurrence and development of ARDS (21). In the whole course of ARDS, the degree of interaction between antiinflammatory factors and pro-inflammatory factors determines the development direction of inflammatory response in ARDS. When the secretion of anti-inflammatory factors is insufficient in the body, it is not enough to resist the body's inflammatory response, which will lead to apoptosis, and exacerbate the damage of organ function, thus increasing the mortality rate of patients (22). Moreover, IL-10 is secreted mainly by helper $\mathrm{T}$ lymphocytes and mononuclear macrophages, and exerts an anti-inflammatory effect through T cells (23). IL-10 restores the balance between anti-inflammatory response and inflammatory response via inhibiting the body's inflammatory response. Studies have found (24) that in the early ARDS patients, the level of IL-10 in BALF is reduced, so it is not enough to exert an anti-inflammatory effect, aggravating inflammatory response in the lung. In this study, it was found that levels of TNF- $\alpha$, IL- 6 and VEGF in serum and BALF of ARDS rats were significantly increased, but the IL-10 levels were significantly decreased. It can be seen that there is an imbalance between anti-inflammatory response and inflammatory response in ARDS rats, and serious inflammatory response occurs.

Glucocorticoids have been applied for a long time in the treatment of ARDS, but their roles in ARDS are still controversial. Some scholars believe that the long-term application of high-dose glucocorticoids has side effects, such as osteoporosis, elevated blood glucose and aggravated infection. However, the application of glucocorticoids indeed has a positive effect in the treatment of ARDS in general (25). In this experimental study, it was found that injecting dexamethasone into ARDS rats via the caudal vein could significantly alleviate the body's inflammatory response in ARDS rats, and maintain the balance between anti-inflammatory response and inflammatory response, thereby reducing inflammatory exudation of lung tissues and pulmonary edema, and protecting the lung. Glucocorticoids have a wide range of mechanisms of action in the treatment of ARDS, which can directly or indirectly act on inflammatory cells, reduce myeloperoxidase activity, and inhibit neutrophil activation, thereby alleviating tissue damage (26). At the same time, glucocorticoids can promote the expression of mitogen-activated protein kinase phosphatase-1 in lung tissues, and inhibit expression levels of neutrophil chemokine, monocyte chemoattractant protein-1 and P-selectin, thereby reducing the inflammatory response in lung tissues (27). In addition, glucocorticoids can improve ARDS by alleviating disorders of the alveolus superficial active substance (7). In case of hypoxia in lung tissues, glucocorticoids can maintain the activity of some sodium ion channels, thereby reducing pulmonary edema (28).

In conclusion, this study suggests that there is a serious imbalance between anti-inflammatory response and inflammatory response in rats with ARDS induced by oleic acid combined with LPS of Escherichia coli, whereas dexamethasone can maintain the balance between anti-inflammatory response and inflammatory response through inhibiting expression levels of inflammatory factors (TNF- $\alpha$, IL-6 and VEGF) and promoting the expression of anti-inflammatory factor (IL-10) in serum and BALF, thus alleviating lung tissue injury. The inflammatory response process of ARDS is very complex, involving a variety of cytokines, and other related cytokines remain to be further studied. At the same time, the occurrence mechanism of ARDS is complicated, and whether glucocorticoids can improve ARDS through other signaling pathways also needs to be further studied. 


\section{Acknowledgements}

Not applicable.

\section{Funding}

No funding was received.

\section{Availability of data and materials}

All data generated or analyzed during this study are included in this published manuscript.

\section{Authors' contributions}

MQ designed the study and prepared the manuscript, ZQ was responsible for data collection and analysis, and MQ for fund collection. Both authors read and approved the final manuscript.

\section{Ethics approval and consent to participate}

This study was approved by the Animal Ethics Committee of Shihezi University Animal Center (Shihezi, China).

\section{Patient consent for publication}

Not applicable.

\section{Competing interests}

The authors declare that they have no competing interests.

\section{References}

1. Van den Steen PE, Deroost K, Deckers J, Van Herck E, Struyf S and Opdenakker G: Pathogenesis of malaria-associated acute respiratory distress syndrome. Trends Parasitol 29: 346-358, 2013.

2. Kong MY,Li Y, Oster R, Gaggar A and Clancy JP: Early elevation of matrix metalloproteinase- 8 and -9 in pediatric ARDS is associated with an increased risk of prolonged mechanical ventilation. PLoS One 6: e22596, 2011.

3. Del Sorbo L and Slutsky AS: Ventilatory support for acute respiratory failure: New and ongoing pathophysiological, diagnostic and therapeutic developments. Curr Opin Crit Care 16: 1-7, 2010

4. Grasso S, Stripoli T, De Michele M, Bruno F, Moschetta M, Angelelli G, Munno I, Ruggiero V, Anaclerio R, Cafarelli A, et al: ARDS net ventilatory protocol and alveolar hyperinflation: Role of positive end-expiratory pressure. Am J Respir Crit Care Med 176: 761-767, 2007.

5. Janz DR and Ware LB: Biomarkers of ALI/ARDS: Pathogenesis, discovery, and relevance to clinical trials. Semin Respir Crit Care Med 34: 537-548, 2013.

6. Huang CT, Lin HH, Ruan SY, Lee MS, Tsai YJ and Yu CJ: Efficacy and adverse events of high-frequency oscillatory ventilation in adult patients with acute respiratory distress syndrome: A meta-analysis. Crit Care 18: R102, 2014.

7. Mokra D, Drgova A, Kopincova J, Pullmann R and Calkovska A: Anti-inflammatory treatment in dysfunction of pulmonary surfactant in meconium-induced acute lung injury. Adv Exp Med Biol 756: 189-196, 2013.

8. Kim HA, Park JH, Lee S, Choi JS, Rhim T and Lee M: Combined delivery of dexamethasone and plasmid DNA in an animal model of LPS-induced acute lung injury. J Control Release 156: 60-69, 2011.
9. Matute-Bello G, Frevert CW and Martin TR: Animal models of acute lung injury. Am J Physiol Lung Cell Mol Physiol 295: L379-L399, 2008.

10. Pierrakos C, Karanikolas M, Scolletta S, Karamouzos V and Velissaris D: Acute respiratory distress syndrome: Pathophysiology and therapeutic options. J Clin Med Res 4: 7-16, 2012.

11. Ghosh S, Wilson MR, Choudhury S, Yamamoto H, Goddard ME, Falusi B, Marczin N and Takata M: Effects of inhaled carbon monoxide on acute lung injury in mice. Am J Physiol Lung Cell Mol Physiol 288: L1003-L1009, 2005.

12. Zhou Z, Kozlowski J and Schuster DP: Physiologic, biochemical, and imaging characterization of acute lung injury in mice. Am J Respir Crit Care Med 172: 344-351, 2005.

13. Matthay MA, Zimmerman GA, Esmon C, Bhattacharya J, Coller B, Doerschuk CM, Floros J, Gimbrone MA Jr, Hoffman E, Hubmayr RD, et al: Future research directions in acute lung injury: Summary of a National Heart, Lung, and Blood Institute working group. Am J Respir Crit Care Med 167: 1027-1035, 2003.

14. Prabhakaran P: Acute respiratory distress syndrome. Indian Pediatr 47: 861-868, 2010.

15. Thompson BT and Matthay MA: The Berlin definition of ARDS versus pathological evidence of diffuse alveolar damage. Am J Respir Crit Care Med 187: 675-677, 2013.

16. Seybold J, Thomas D, Witzenrath M, Boral S, Hocke AC, Bürger A, Hatzelmann A, Tenor H, Schudt C, Krüll M, et al: Tumor necrosis factor-alpha-dependent expression of phosphodiesterase 2: Role in endothelial hyperpermeability. Blood 105: 3569-3576, 2005.

17. Liu YD, Liu W and Liu Z: Influence of long-term drinking alcohol on the cytokines in the rats with endogenous and exogenous lung injury. Eur Rev Med Pharmacol Sci 17: 403-409, 2013.

18. Li T, Luo N, Du L, Liu J, Gong L and Zhou J: Early and marked up-regulation of TNF- $\alpha$ in acute respiratory distress syndrome after cardiopulmonary bypass. Front Med 6: 296-301, 2012.

19. MacLaren R and Stringer KA: Emerging role of anticoagulants and fibrinolytics in the treatment of acute respiratory distress syndrome. Pharmacotherapy 27: 860-873, 2007.

20. Mura M, dos Santos CC, Stewart D and Liu M: Vascular endothelial growth factor and related molecules in acute lung injury. J Appl Physiol (1985) 97: 1605-1617, 2004.

21. Cabebe E and Wakelee H: Sunitinib: A newly approved smallmolecule inhibitor of angiogenesis. Drugs Today (Barc) 42: 387-398, 2006.

22. Bhatia M and Moochhala S: Role of inflammatory mediators in the pathophysiology of acute respiratory distress syndrome. J Pathol 202: 145-156, 2004.

23. Miura Y, Nishimura Y, Katsuyama H, Maeda M, Hayashi H, Dong M, Hyodoh F, Tomita M, Matsuo Y, Uesaka A, et al: Involvement of IL-10 and Bcl-2 in resistance against an asbestosinduced apoptosis of T cells. Apoptosis 11: 1825-1835, 2006.

24. Fumeaux T and Pugin J: Role of interleukin-10 in the intracellular sequestration of human leukocyte antigen-DR in monocytes during septic shock. Am J Respir Crit Care Med 166: 1475-1482, 2002.

25. Meduri GU, Marik PE, Chrousos GP, Pastores SM, Arlt W, Beishuizen A, Bokhari F, Zaloga G and Annane D: Steroid treatment in ARDS: A critical appraisal of the ARDS network trial and the recent literature. Intensive Care Med 34: 61-69, 2008.

26. Sombra MA, Vasconcelos MP, Guimarães SB, Escalante RD, Garcia JH and Vasconcelos PR: Acute pulmonary injury induced by experimental muscle trauma. Acta Cir Bras 26 (Suppl 1): 43-46, 2011.

27. Yubero S, Manso MA, Ramudo L, Vicente S and De Dios I: Dexamethasone down-regulates the inflammatory mediators but fails to reduce the tissue injury in the lung of acute pancreatitis rat models. Pulm Pharmacol Ther 25: 319-324, 2012.

28. Urner M, Herrmann IK, Booy C, Roth-Z'Graggen B, Maggiorini $M$ and Beck-Schimmer B: Effect of hypoxia and dexamethasone on inflammation and ion transporter function in pulmonary cells. Clin Exp Immunol 169: 119-128, 2012.

(i) $\ominus$ This work is licensed under a Creative Commons Attribution-NonCommercial-NoDerivatives 4.0 International (CC BY-NC-ND 4.0) License. 